\title{
The Effect of The Company's Liquidity Ratio and Size on The Value of Agricul- tural Companies
}

\author{
Agus Darmawan*, Yusuf Iskandar, Heliani \\ Nusa Putra University, West Java, Indonesia
}

*Corresponding author:

E-mail: Agus.darma-

wan_mn18@nusaputra.ac.id

\begin{abstract}
This analysis aims to examine the impact of liquidity and firm size on firm valuation by analyzing empirical evidence from firms that went public on the Indonesia Stock Exchange between 2015 and 2017. Between 2015 and 2017, the population for this study consisted of 22 firms that were classified on the Indonesian Stock Exchange. Purposive sampling was used to collect data. The sample parameters are as follows: (1) firms that have always presented earnings results annually between 2015 and 2017, and (2) companies that have continued to pay dividends annually between 2015 and 2017. The data is derived from articles on the IDX database, which can be accessed at www.idx.co.id. During the past four years, there have been 16 businesses sampled. The regression analysis methodology was used in this study. The findings indicate that firm liquidity has a favorable and statistically relevant impact on firm valuation. The scale of the company has a detrimental and marginal effect on the firm's value.
\end{abstract}

Keywords: Liquidity ratio, firm size, firm value.

\section{Introduction}

Companies raise capital in a variety of forms, one of which is by the sale of stock to buyers. Stocks provide investors an attractive rate of return, making them one of the most common in-vesting tools. However, although stocks enable investors to earn high returns, they often expose investors to high risks, as Keynes stated in investment law, namely "high risk, high reward," where the greater the risk, the greater the return. Investors undoubtedly want to increase their wellbeing by anticipating profits from purchasing or holding securities, specifically capital returns and dividends. On the other side, businesses need constant funding to expand and survive, as well as to boost the health of their owners. As a result, investors must use caution when purchasing shares to avoid purchasing the incorrect ones, which would imply purchasing shares that are not beneficial or perhaps harmful to the investor. To avoid purchasing the incorrect stock, investors must exercise caution when evaluating the business from which they plan to acquire shares.

The Price to Book Value ratio will be used to determine a company's value. A high price to book value demonstrates the company's reputation and profitability, convincing customers that the company's potential prospects would be favorable and profitable. They conclude that the worth of a company is calculated solely by its potential to earn income and its business risk. According to Litzenberger and Ramaswamy in 1979, dividends are generally more taxable than capital gains, which causes investors to demand a higher rate of return. Numerous variables im-pact dividend strategy and may have a direct or indirect effect on firm valuation. These considerations include the scale of the business (Soliha \& Taswan, 2002), the liquidity of the business (Nurhayati, 2008), and the size of the business (Rahmawati \& Akram, 2007; Puspita, 2009). Through evaluating these factors, this analysis can determine the effect of liquidity and firm size on firm valuation.

Agricultural companies are attractive investments, as Indonesia is an agricultural nation endowed with abundant natural capital. The larger the farming corporation, the greater the amount of natural

How to cite:

Darmawan, A., Iskandar, Y., \& Heliani. (2021). The effect of the company's liquidity ratio and size on the value of agricultural companies. $1^{\text {st }}$ ICEMAC 2020: International Conference on Economics, Management, and Accounting. NST Proceedings. pages 334-342. doi: 10.11594/ nstp.2021.1038 
capital it manages. Like too many natural resources being handled, the company's cash and inventory would undoubtedly rise, allowing these short-term investments to be utilized to cover corporate debts. As a result, we may conclude that the scale of the business and the liquidity ratio of the business have an impact on the valuation of agricultural firms. As a result, something needs to be examined.

\section{Literature Review}

\section{The value of the company}

The extent of the prosperity of a business may be determined by its market valuation. Thus, shareholders, as owners of the company, would desire a high return for their investment. According to Indahwati (2003), the market valuation ratio informs management of investors' perceptions of the company's previous success and potential expectations. The price to book value (PBV) ratio is one method for determining a company's value. The PBV ratio is the ratio of the share price to the per-sheet book value of the stock. The PBV ratio indicates the extent to which a business may generate profit concerning the sum of investment resources.

\section{Effect of liquidity on firm value}

- The greater the company's liquidity, the more funds are accessible to pay dividends, finance activities, and spend, which improves investors' expectations of the company's results. The share price will rise, while the PBV will improve. In certain circumstances, increasing liquidity may result in negative expectations. If an improvement in liquidity would not increase distributions but rather in the company's free cash flow, agency expenses will rise. The evolution of liquidity commonality before and after the global financial crisis has received way too little attention (Yao \& Luo, 2009). As a result, the following observation is made:

- Ho: There is no significant effect between LnCR and LnPBV

- Ha: There is a significant effect between LnCR and LnPBV

\section{The effect of firm size on firm value}

Soliha and Taswan (2002) assert that a firm's scale has a positive and substantial impact on its worth. Big firms typically have wider access to the stock market, since they are more well-known to investors, providing them with greater stability and willingness to raise capital. Since access to the stock market is adequate, stability and capacity to collect funds are increased. This is seen positively by investors as an indication of strength and future growth, implying that business size has a favorable effect on company valuation. s. Romano (1996) and Cyert et al. (1998) both address the significance of major shareholders in determining the firm's worth. Additionally, Holderness and Sheehan (1988) discover that the disclosure of plurality block trades results in favorable stock returns. Crystal (1991), Jensen (1993), and Byrne (1996) both assert that increasing management and board of director equity ownership results in increased shareholder valuation.

The following observation is then made:

Ho: There is no significant effect between LnSize and LnPBV

Ha: There is a significant influence between LnSize and LnPBV

\section{Research Methods Research variable}

The dependent variable (bound) and the independent variable are also used in this study (free). Two independent variables and one dependent variable were included in this study. The Price Book Value is the dependent variable in this analysis. Meanwhile, the current ratio and the company's scale are separate factors. 


\section{Object of research}

This thesis focused on the subject of science, agricultural businesses. The study's population consisted of 22 agricultural firms that were publicly traded on the Indonesian Stock Exchange.

\section{Sample determination}

This study was conducted using a sample of sixteen publicly traded stocks on the Indonesian Stock Exchange. The sample was chosen using purposive sampling. The following parameters were used to select samples for this study:

1. From 2015 to 2017, the Indonesia Stock Exchange reported 22 agricultural firms.

2. From 2015 to 2017, agricultural firms listed on the Indonesian Stock Exchange refused to report current ratios, total assets, or book value for six businesses. Agricultural companies that were listed consecutively on the Indonesian Stock Exchange from 2015 to 2017 and completely reported their current ratio, total assets, and PBV data.

Table 1 List of companies

\begin{tabular}{lll}
\hline No. & Stock code & Issuer Name \\
\hline 1 & ANJT & Austindo Nusantara Jaya Tbk. \\
2 & BISI & Bisi International Tbk. \\
3 & BWPT & Eagle High Plantations Tbk. \\
4 & DSFI & Dharma Samudera Fishing Industries Tbk. \\
5 & DSNG & Dharma Satya Nusantara Tbk. \\
6 & GOLL & Golden Plantation Tbk. \\
7 & GOZCO & Gozco Plantations Tbk. \\
8 & JAVA & Jaya Agra Wattie Tbk. \\
9 & LSIP & PP London Sumatra Indonesia Tbk. \\
10 & MAGP & Multi Agro Gemilang Plantation Tbk. \\
11 & PALM & Provident Agro Tbk. \\
12 & SGRO & Sampoerna Agro Tbk. \\
13 & SIMP & Salim Ivomas Pratama Tbk. \\
14 & SMAR & SMART Tbk. \\
15 & SSMS & Sawit Sumbermas Sarana Tbk. \\
16 & UNSP & Bakrie Sumatera Plantations Tbk. \\
\hline
\end{tabular}

\section{Data collection technique}

The evidence for this study came from secondary sources such as previous scholarly journals, literature, and financial statement records from businesses.

\section{Method of analysis}

This work, like Nurhayati's (2013), would use multiple regression analysis. With two stages of research, the classic inference test, especially the normality test, the multicollinearity test, and the autocorrelation test. Following that, a hypothesis evaluation is conducted with a validity amount of 0.05 . Following that, we conducted a simultaneous evaluation (f test), a determination coefficient test (R2), and a minimal test (t-test). In this analysis, there are three variables: two independent variables and one dependent variable. The formula for multiple linear regression used in this analysis is as follows:

$\mathrm{PBV}=\alpha+\beta 1 \mathrm{CR}+\beta 2$ Size $+\varepsilon$

Where :

PBV: Price Book Value

$\alpha$ : Constants 


\section{CR: Current Ratio}

Size: Company Size

$\varepsilon:$ error

\section{Variable definition and measurement}

The test variables used are almost identical to those used in Nurhayati's (2013) study. It's just that the factors in this analysis do not include dividend strategy or firm profitability. The variables used in this analysis are operationally described and quantified as follows:

Endogenous variables (Endogenous variable), namely:

a. Firm Value (PBV)

Market to book value (MBV) or Price to Book Value (PBV)is one of the metrics used to evaluate investors when evaluating a company. This ratio relates the per-sheet share price to the per-sheet book value of shares. The greater the significance placed on this ratio, the more lucrative the company (Nurhayati, 2008). The market value of equity is calculated by multiplying the number of issued shares of common stock by the stock price on the last day of the year. Insiders' percentage ownership is calculated as the number of securities owned by business insiders divided by the number of issued common stock shares. (Navissi, \& Naiker, 2006).

This ratio is calculated using the formula as below:

$P B V=\frac{\text { stock price }}{\text { Book value of equity per sheet }}$

Exogenous variables, namely:

a. Company Size (SIZE)

The SIZE symbol denotes the company measurement variable. The natural logarithm of the book value of assets is used to calculate this variable (Soliha \& Taswan, 2002 in Nurhayati 2008). The number of stock owned by retail and corporate investors is then classified as passive or aggressive, depending on their position on the company's board of directors. To account for dimension, the natural logarithm of the book value of assets is used in the formula (Craswell et al., 1997).

SIZE $=$ Natural Logarithm of Company Total Assets Value

\section{b. Company Liquidity}

The current ratio is an alternative to the liquidity ratio of a company. This ratio indicates a company's willingness to meet its existing obligations with its current assets. Assume that the company's existing investments are turned to capital to be used to pay down its current liabilities. The expression for the present ratio is as follows:

Current Ratio $=($ Current assets $) /($ Current Liability $)$

\section{Results and Discussion}

Model assumptions are validated using the data normality and model suitability tests. The Kolmogorov Smirnov test was used to determine the normality of the data (Ghozali, 2005). The data were subjected to a classic inference test before a multiple regression study. The study results were shown to be free of multicollinearity and autocorrelation disorders. Following that, the classical assumption test was conducted using two independent variables to ensure that all of the classical assumption test's conditions were fulfilled. 
Table 2. One-sample Kolmogorov-Smirnov test before data transformation using Ln

Unstandardized Residual

\begin{tabular}{lll}
\hline N & & 48 \\
\hline Normal Parametersa, b & Mean &, 0000000 \\
\cline { 2 - 3 } & Std. Deviation & 1.02362753 \\
\hline Most Extreme Differences & Absolute &, 226 \\
\cline { 2 - 3 } & Positive &, 226 \\
\cline { 2 - 3 } & Negative &,- 167 \\
\hline Statistical Test & &, 226 \\
\hline Asymp. Sig. (2-tailed) & &, $000 \mathrm{c}$ \\
\hline Source: Processed by & &
\end{tabular}

Source: Processed by IBM SPSS

Table 2 shows that the Asymp value. Sig. (2-tailed) $=0.000<0.05$ which indicates the data is not normally distributed. Due to the non-normal nature of the data, it is important to convert it using natural logarithms. The below are the effects of the data transformation:

Table 3. One-sample Kolmogorov-Smirnov test after data transformation using Ln Unstandardized Residual

\begin{tabular}{lll}
\hline N & & 48 \\
\hline Normal Parametersa, $\mathrm{b}$ & Mean &, 0000000 \\
\cline { 2 - 3 } & Std. Deviation &, 67782084 \\
\hline Most Extreme Differences & Absolute &, 110 \\
\cline { 2 - 3 } & Positive &, 089 \\
\cline { 2 - 3 } & Negative &,- 110 \\
\hline Statistical Test & &, 110 \\
\hline Asymp. Sig. (2-tailed) & &, $195 \mathrm{c}$ \\
\hline
\end{tabular}

\section{Source: Processed data, IBM SPSS}

Table 3 shows the results after being transformed with natural logarithms, the Asymp values are obtained. Sig. (2-tailed) $=0.195>0.05$ which indicates the data has been normally distributed. The next stage is to perform the Multicollinearity Test. The results of the multicollinearity test are as follows: 


\begin{tabular}{|c|c|c|c|c|}
\hline \multicolumn{2}{|c|}{ Model } & \multicolumn{2}{|l|}{ Collinearity Statistics } & Information \\
\hline \multirow[t]{3}{*}{1} & (Constant) & & & Multicollinearity Free \\
\hline & LnCR &, 970 & 1,031 & Multicollinearity Free \\
\hline & LnSize &, 970 & 1,031 & Multicollinearity Free \\
\hline
\end{tabular}

Source: Data processed by IBM SPSS

According to table 4 , the tolerance value for both independent variables is 0.970 , which is greater than 0.10 . Although each has a VIF value of $1.031<10.00$. Then, by referring to the multicollinearity test's decision-making basis, it is possible to conclude that multicollinearity does not exist. The autocorrelation test is needed following the multicollinearity test. The following table summarizes the findings:

Table 5. Autocorrelation

\begin{tabular}{|c|c|c|c|c|c|}
\hline \multicolumn{6}{|c|}{ Model Summary ${ }^{b}$} \\
\hline Model & $\mathrm{R}$ & R Square & $\begin{array}{l}\text { Adjusted R } \\
\text { Square } \\
\end{array}$ & $\begin{array}{l}\text { Std. Error of the } \\
\text { Estimate }\end{array}$ & Durbin-Watson \\
\hline 1 &, $597^{\mathrm{a}}$ & ,357 & ,328 &, 69272 & 2,235 \\
\hline
\end{tabular}

a. Predictors: (Constant), LnSize, LnCR

b. Dependent Variable: LnPBV

Source: Data processed by IBM SPSS

Table 5 shows the value is 2,235 , while in the DW table for " $\mathrm{k} "=3$ and $\mathrm{N}=16$, the DW-table size is: $\mathrm{dL}=0.857$ and $\mathrm{dU}=1.728,4-\mathrm{dl}=3.143$, and $4-\mathrm{dU}=2.272$. DW value of $2,235>$ limit $\mathrm{dU} 1.728$ and less than 4-1.728 (4-du), It can be inferred that the study findings $(1.728<2,235<2,272)$ there is no autocorrelation.

The F statistical test shows whether all the included independent variables have a joint effect on the dependent variable (Aspara \& Indriani, 2017). The results of the statistical test of this study can be seen in the following table:

Table 6. Simultaneous test (Test F)

ANOVAa

\begin{tabular}{lll|l|l|l|l} 
Model & & Sum of Squares & df & Mean Square & F & Sig. \\
\hline 1 & Regression & 11,978 & 2 & 5,989 & 12,480 &, $000 \mathrm{~b}$ \\
\cline { 2 - 7 } & Residual & 21,594 & 45 &, 480 & & \\
\cline { 2 - 7 } & Total & 33,571 & 47 & & & \\
\hline
\end{tabular}

a. Dependent Variable: LnPBV

b. Predictors: (Constant), LnSize, LnCR

Source: data processed by IBM SPSS

As seen in Table 6, all independent variables have a statistically important impact on the dependent variable. The table above indicates that there are 12,480 and Ftable is 3,74 with a chance of $0 \%$. This 
demonstrates that the current ratio and the scale of the business have an impact on the price to book value ratio.

Table 7. Test of the coefficient of determination

\section{Model Summary b}

\begin{tabular}{|c|c|c|c|c|c|}
\hline Model & $\mathrm{R}$ & R Square & Adjusted R Square & $\begin{array}{l}\text { Std. Error of the } \\
\text { Estimate }\end{array}$ & Durbin-Watson \\
\hline 1 &, $597 a$ &, 357 &, 328 &, 69272 & 2,235 \\
\hline
\end{tabular}

a. Predictors: (Constant), LnSize, LnCR

b. Dependent Variable: LnPBV

Source: Data processed by IBM SPSS

The coefficient of determination $\left(\mathrm{R}^{\wedge} 2\right)$ measure is used to determine how much difference in the dependent variable is explained by the ability of the independent variables in the model (Aspara \& Indriani, 2017). The value of the coefficient of determination $\left(\mathrm{R}^{\wedge} 2\right)$ is between 0 and 1 . A value close to one Explains that the independent variables almost provide all the information needed to estimate the dependent variables (Aspara \& Indriani, 2017). The results from the table above value $\mathrm{R}^{\wedge} 2$ on the column Adjusted R Square is 0.357 or $35.7 \%$, this shows the ability of the Current Ratio variable and company size in explaining the Price to books value variable is $35.7 \%$. Next, we need to do a Partial Test (T-Test). The results obtained are as in table 8.

Table 8. Partial test (t-test)

\section{Coefficients}

\begin{tabular}{|c|c|c|c|c|c|c|}
\hline \multirow[b]{2}{*}{ Model } & & \multicolumn{2}{|c|}{ Unstandardized Coefficients } & \multirow{2}{*}{$\begin{array}{l}\text { Standardized } \\
\text { Coefficients } \\
\text { Beta }\end{array}$} & \multirow[b]{2}{*}{$\mathrm{t}$} & \multirow[b]{2}{*}{ Sig. } \\
\hline & & $\mathrm{B}$ & Std. Error & & & \\
\hline \multirow[t]{3}{*}{1} & (Constant) & 2,113 & 3,189 & &, 663 &, 511 \\
\hline & LnCR &, 450 &, 090 &, 604 & 4,978 &, 000 \\
\hline & LnSize & $-1,527$ & 1,182 &,- 157 & $-1,292$ &, 203 \\
\hline
\end{tabular}

a. Dependent Variable: LnPBV

Source: Data processed by IBM SPSS

Based on the results in table 8 above, the multiple linear regression equation is obtained as follows.

$$
\operatorname{LnPBV}=2,113+0,450 \operatorname{LnCR}-1,527 \operatorname{LnSize}+\boldsymbol{\varepsilon} \boldsymbol{i}
$$

From the above equation, It can be explained that a constant of 2.113 states that if LnCR, and LnSize are 0 , then LnPBV is 2.113 The significance value ( $\mathrm{Sig}$ ) of the variable Current ratio (X1) is 0,000 . Because of the Sig. $0.000<0.05$ probability. This means that there is an effect of the Current ratio (X1) on PBV (Y). While The significance value (Sig) of the size variable (X1) is 0,000. Because of the Sig. $0.208>0.05$ probability. This means that there is no effect of size (X1) on PBV (Y).

The regression coefficient for the LnCR variable is 0.450 , meaning that if the other independent variables are fixed in value and LnCR increases by $1 \%$, then LnPBV will increase by 0.450 , the coefficient is positive, meaning that there is a positive relationship between LnCR and LnPBV, the higher the LnCR, the higher the LnPBV.

The regression coefficient for the LnSize variable is -1.527 , meaning that if other independent variables are fixed in value and LnSize has increased by $1 \%$, then LnPBV will experience a decrease of 1.527, the coefficient is negative, meaning that there is a negative relationship between LnSize and LnPBV, the higher the LnSize, the lower the LnPBV.

To prove the effect of each independent variable partially or individually on the dependent variable, $\mathrm{t}$ test analysis was used. To determine the effect partially, namely: LnCR and LnSize on LnPBV. 
The test steps are as follows:

1. Current Ratio (LnCR) to Price to Book Value (LnPBV) :

o Ho: There is no significant effect between LnCR and LnPBV

o Ha: There is a significant effect between LnCR and LnPBV

Utilizing a large volume of $0.05 / 2=0.025$ (two-sided test) With degrees of freedom (df) nk-1 or $16-3-1=12$, so that the $t$ table is known to be 2.179 Based on the output in table 8 it shows the $t$ value of 4,978. The decision-making criteria are:

- $\quad t$ count $<\mathrm{t}$ table then Ho is accepted

- $\quad t$ count $>t$ table then Ho is rejected

Because the value of $t$ count $>t$ table $(4.978>2.179)$, it can be concluded that the new ratio has a measurable influence on the Price Book Value. This is inversely proportional to Nurhayati, 2013 where her research shows that the current ratio does not have a significant impact on firm value.

2. Company size (LnSize) against Price to Book Value (LnPBV):

Ho: There is no significant effect between LnSize and LnPBV

Ha: There is a significant influence between LnSize and LnPBV

Using a significant level of $0.05 / 2=0.025$ (two-sided test) With degrees of freedom (df) nk-1 or 16-3-1 $=12$, so that the $\mathrm{t}$ table is known to be 2.179 Based on the output in table 8 shows the $t$ value of $-1,292$. The decision-making criteria are:

- $\quad t$ count $<\mathrm{t}$ table then Ho is accepted

- $\quad t$ count $>t$ table then Ho is rejected

Because the value of $t$ count $<t$ table $(-1.292<2.179)$, it can be concluded that the size of a company has no discernible impact on This is inversely proportional to Nurhayati, 2013 wherein her research results show that company size has a significant impact on firm value.

There tends to be a disparity in the outcomes obtained by linear regression analysis between the parallel and incomplete tests. Where the stimulant test findings indicate that the two variables $\mathrm{X}$ have a statistically important impact on variable Y. Meanwhile, the findings of the partial test indicate that business size has no major impact on PBV.

\section{Conclusion}

This research yielded several conclusions, including the following:

1. According to the test findings, the current ratio (CR) has a favorable and statistically meaningful impact on the dependent variable, namely price to book value. As a result, when CR rises, PBV increases as well.

2. According to the test findings, the size of the company (Value) has a detrimental and negligible impact on market values. As a result, when the Size rises, the stock price decreases.

\section{References}

Aspara, H. R., \& Indriani, A. (2017). Analisis pengaruh crude oil price, earning per share, price to book value, return on assets dan debt to equity ratio terhadap harga saham perusahaan batubara yang terdaftar di Bursa Efek Indonesia Periode 2012-2016. Diponegoro Journal of Management, 6(4), 2337-3792.

Byrne, J.A. (1996). The best and worst boards. Business Week, November 25.

Craswell, T. A., Taylor, S. L., \& Saywell, R. A. (1997). Ownership structure and corporate performance: Australian evidence. Pacific-Basin Finance Journal, 5, 301-23.

Crystal, G. (1991). In search of excess: The overcompensation of american executives, W.W. Norton Company, New York, NY.

Cyert, R., Kang, S., \& Kumar, P. (1998). Corporate governance and top management compensation with incomplete contracts: theory and evidence. working paper. Yale School of Management

Ghozali, I. (2005). Aplikasi analisis multivariate dengan program SPSS.

Holderness, C. G., \& Sheehan, D. P. (1988). The role of majority shareholders in publicly held corporations: an exploratory analysis. Journal of Financial Economics, 20, 317-40.

Indahwati. (2003). Analisis pengaruh leverage dan kebijakan struktur modal terhadap kebijakan utang dan nilai perusahaan go publik pasar modal Indonesia Selama Krisis 1998-2001. Disertasi. Program Pascasarjana Universitas Brawijaya, Malang. 
Jensen, M. (1993). The modern industrial revolution, exit, and the failure of internal control systems. Journal of Finance, 48, 831-80 Navissi, F., \& Naiker, V. (2006). Institutional ownership and corporate value. Managerial Finance, 32(3), $247-256$.

Nurhayati, Mafizatun. (2008). Pengaruh struktur kepemilikan, profitabilitas, dan ukuran perusahaan terhadap kebijakan hutang dan kebijakan dividen dalam penciptaan nilai perusahaan : Studi empirik pada perusahaan sektor non jasa di bursa efek Jakarta. Tesis. Universitas Budi Luhur Jakarta.

Nurhayati, M. (2013). Profitabilitas, likuiditas dan ukuran perusahaan pengaruhnya terhadap kebijakan dividen dan nilai perusahaan sektor non jasa. Jurnal Keuangan dan Bisnis, 1, 117-123.

Puspita, Fira. (2009). Analisis faktor-faktor yang mempengaruhi kebijakan dividend payout ratio: Studi kasus pada perusahaan yang terdaftar di bursa efek Indonesia Periode 2005-2007. Tesis. Universitas Diponegoro. Semarang.

Rahmawati, Intan dan Akram. (2007). Faktor-faktor yang Mempengaruhi Kebijakan Dividen dan Pengaruhnya terhadap Nilai Perusahaan pada Perusahaan-Perusahaan di BEJ Periode 2000 - 2004. Jurnal Riset Akuntansi Aksioma, 6(1), 1-10.

Romano, R. (1997). Pension funds and corporate governance. Working paper. Yale Law School.

Soliha, E., \& Taswan. (2002). Pengaruh kebijakan hutang terhadap nilai perusahaan serta beberapa faktor yang mempengaruhinya. Jurnal Bisnis dan Ekonomi, 1(1), 1-5.

Yao, S., \& Luo, D. (2009). The economic psychology of stock market bubbles in China. World Economy, 32, 667-691. 